\title{
Lusotopie
}

Recherches politiques internationales sur les espaces issus de l'histoire et de la colonisation portugaises

$\mathrm{XIX}(1) \mid 2020$

Amílcar Cabral et l'idée de la révolution anticoloniale

\section{The PAIGC ‘Congratulatory' Diplomacy towards Communist States, 1960-1964}

La diplomatie «congratulatoire » du PAIGC envers les États communistes, 1960-1964

A diplomacia "congratulatória" do PAIGC para com os estados comunistas, 1960-1964

\section{Abel Djassi Amado}

\section{(2) OpenEdition \\ Journals}

Electronic version

URL: https://journals.openedition.org/lusotopie/4640

ISSN: 1768-3084

\section{Publisher}

Idemec - UMR 7307

\section{Printed version}

Date of publication: 4 August 2020

Number of pages: $54-75$

ISSN: 1257-0273

Electronic reference

Abel Djassi Amado, "The PAIGC 'Congratulatory' Diplomacy towards Communist States, 1960-1964", Lusotopie [Online], XIX(1) | 2020, Online since 02 January 2022, connection on 04 February 2022. URL: http://journals.openedition.org/lusotopie/4640

This text was automatically generated on 4 February 2022.

Lusotopie 


\title{
The PAIGC 'Congratulatory' Diplomacy towards Communist States, 1960-1964
}

\author{
La diplomatie « congratulatoire » du PAIGC envers les États communistes, \\ 1960-1964 \\ A diplomacia "congratulatória" do PAIGC para com os estados comunistas, \\ 1960-1964
}

Abel Djassi Amado

1 Portugal's unwillingness to decolonize, at a time when other European powers in Africa were departing, forced African nationalists to fully engage in the politics of armed liberation struggle. The African Party for the Independence of Guinea-Bissau and Cabo Verde (PAIGC) was one of the many parties involved in a multi-dimensional and complex political struggle against the Portuguese colonial state. Foreign policy and diplomacy were important elements of the struggle carried out by the PAIGC and its leadership, chiefly its Secretary-General, Amílcar Cabral (Cabral 1974, 1979, Dhada 1993, 1995, Gleijeses 2002, Chabal 2003, Godinho 2010, Lopes 2012). The origins of the PAIGC diplomatic enterprise can be traced to May 1960, when the party began to develop a diplomatic offensive towards not only African states but also states from other regions of the world. Through active diplomatic engagement, the PAIGC sought to collect and aggregate support - material, moral, and otherwise - from governments and organizations around the world (Dhada 1995, Fistein 2014).

2 One special group of states, the communist bloc, drew particular attention from the leaders of the PAIGC. This paper analyzes the origins and development of the PAIGC's diplomatic offensive towards this group of states, chiefly [the former] Czechoslovakia, the Union of Soviet Socialist Republics (USSR), and the People's Republic of China (PRC). This paper critically examines the development of the PAIGC's foreign policy from May 1960 to February 1964. The choice of the two dates is not random. May 1960 is the month that Cabral moved to Conakry to set up a section of the PAIGC, which would play 
a central role in diplomatic engagement. I limit the analysis to February 1964, a year after the start of the armed liberation struggle. It was at the time that the party held the Congress of Cassaca, which radically transformed the structure of the organization. The changes in the party's political structures eventually led to a change of focus on foreign policy. By the end of the decade, the PAIGC's diplomatic scope had become far more encompassing.

3 In the first years of the 1960s, Amílcar Cabral and the party he led, the PAIGC, carried out two interconnected diplomatic strategies that can be called 'shoeleather' diplomacy and 'congratulatory' diplomacy. I introduce these two concepts to adequately and aptly capture the rather complex schemes, plans of action, and approaches devised by Cabral to link with foreign governments in Africa and elsewhere, in order to attract a myriad of material and non-material resources for the goal of national liberation. The strategy of shoe-leather diplomacy, initiated in mid-1960 in Conakry, focused on the Guinean government and the embassies based in the country. Shoe-leather diplomacy consisted of direct and face-to-face interviews with Guinean and foreign officials based in Conakry. Congratulatory diplomacy, on the other hand, was developed in late 1960, and consisted of indirect political communication. Through letters and cables, the PAIGC celebrated national days of other states and, by so doing, the party hoped to strengthen its relations with these governments.

4 This paper draws extensively on the archives of Amílcar Cabral and the PAIGC, organized and available online through the project Casa Comum (www.casacomum.org), led by the Mário Soares Foundation (Portugal). The materials, recently made available to the public, include not only published documents, such as the party's newsletter (Libertação), letters, cables, reports, and other types of official papers, but also rough papers, including informal notes taken during meetings that allow the reader to get a better picture of key themes and topics discussed and debated at the time.

5 Apart from this brief introduction, this paper consists of three sections. In the next section, I discuss the motives and the key bodies of the party tasked with developing and carrying out its foreign policy. Then, I critically explore the history of the PAIGC's diplomatic offensive towards the communist states, focusing on three main targets, namely, the Soviet Union, Czechoslovakia, and the PRC. Following this section, I explain the notion of congratulatory diplomacy and its core objectives. Finally, in the conclusion, I emphasize how unique the diplomatic engagement was to the PAIGC in the context of liberation movements in Africa.

\section{The PAIGC Diplomacy of Liberation}

6 The PAIGC foreign policy stood on two key pillars. First, the process of foreign policy making was centralized. Two organisms of the party, the Political Bureau and the Secretariat General, exercised full authority to design and implement the diplomacy of national liberation - including the power to initiate political communication with external actors. A second important aspect of the PAIGC's foreign policy making relates to its institutionalization and bureaucratization. Meetings among leadership were common and served as an internal forum to analyse different aspects of the struggle as well as to design appropriate responses to the ever-changing situations. The PAIGC emphasized the maintenance of archival material, a sine qua non for institutional memory (Chilcote 1972). 
7 In the period under analysis (1960-1964), the PAIGC's foreign policy centred on four interrelated objectives. The PAIGC initial diplomatic offensive was part of a strategy to gain political recognition as a serious and legitimate representative of the peoples of Cabo Verde and Guinea-Bissau by demonstrating its resolve to carry out the politics of national independence. One of the founders of the PAIGC and later its SecretaryGeneral, Aristides Pereira, looking back at the history of the party, writes that one of the main concerns of the organization was to "make the authorities [of the Republic of Guinea] recognize that we were a liberation movement that was seriously working" (Lopes 2012: 88, italics added). As such, diplomacy was an important tool through which the PAIGC constructed its image as a politically active organization, with capacity and resolve to meet its political objectives.

8 A second main objective of the PAIGC's foreign policy concentrated on the political neutralization of its main adversaries operating in Dakar, Senegal, and/or in Conakry, Guinea. From the late 1950s to about 1963, those two West African capitals were the arena of active and competitive anticolonial politics carried out by diasporic citizens of Cabo Verde and Guinea-Bissau. At the time, Dakar had fourteen political organizations that claimed to represent and fight for the independence of Guinea-Bissau and Cabo Verde (Ibid., Sousa 2016: 248-253). ${ }^{1}$ The PAIGC leadership was aware that anticolonial politics were fragmented and, on several occasions, under pressure from external actors, such as Guinea and Senegal, sought to construct a united front of nationalist organizations. Pressured by the leaders of the Republic of Guinea, the PAIGC linked with other nationalist movements in November 1960 to form the ephemeral Liberation Movement of Guinea and Cabo Verde (MLGCV). ${ }^{2}$ A year later, in July 1961, pressured by Leopold Senghor, the PAIGC linked with several other political organizations of Guineans and Cabo Verdeans based in Dakar. The resulting organization, the United Front of Liberation (FUL), never materialized. ${ }^{3}$ Political animosity and distrust among liberation movements and their leaders were the two main factors for the derailing of the united front politics. By 1962, it became clear to the party that the efforts towards a united front were a waste of resources.

9 The failure of united front politics gave rise to the politics of damaging the adversary. Both the PAIGC and its political opponents were engaged in the political game of undermining the image of the other side before foreign chancelleries and governments. For instance, in December 1960, the Movement for Liberation of Guinea (MLG) wrote to the Political Bureau of the Democratic Party of Guinea (PDG), claiming that the PAIGC could not speak for the people of Guinea-Bissau as it was formed essentially by Cabo Verdeans. ${ }^{4}$ Similar actions were carried out by the PAIGC. On August 13, 1962, Amílcar Cabral wrote a letter to the ambassador of the Republic of Algeria in Conakry, after learning about a possible military cooperation between the Algerian Army of National Liberation (ALN) and one of the PAIGC's main competitors, the Union of the Populations of 'Portuguese' Guinea (UPG). The letter argued that the UPG did not have a single representative inside Guinea-Bissau and was led by a Senegalese citizen. In essence, Cabral argued the UPG was not a legitimate Bissau-Guinean political organization and condemned any cooperation with it as "involuntarily fomenting" fragmentation among anticolonial nationalists. ${ }^{5}$

10 A third major objective of the PAIGC diplomacy of liberation centered on aggregating political support against the Portuguese government in major arenas of international politics, particularly within the United Nations (UN) system (Silva 1995, Reis 2013, 
Santos 2017). Given the fact that Portugal had effectively imposed a wall of silence around its colonies and continuously refused to submit information on the colonies as mandated by the UN, the PAIGC became one of the key channels through which foreign governments - and international organizations - could build knowledge about the political conditions inside the Portuguese colonies.

11 The last main goal of foreign policy was to obtain material support from foreign governments - or, in the PAIGC parlance, "concrete aid." ${ }^{6}$ By late 1959, the leadership of the party had made the decision that national independence of Cabo Verde and Guinea-Bissau meant engaging in "direct action," that is, direct military actions against the Portuguese colonial state. The fulfillment of this strategy required not only military training of party cadres and rank-and-file but also the financing and stocking of war material. Through the application of different methods, ranging from direct contact with embassy officials and foreign diplomats to letter-writing, the PAIGC sought to obtain financial resources and material equipment for its military units. The PRC and Czechoslovakia were among the first to positively offer military cooperation, respectively, providing military training and the first lot of weaponry.

\section{The PAIGC's Foreign Policy towards the Communist Bloc}

12 The involvement of the communist bloc in the liberation struggle in Portuguese colonies dates back to May $1960 .^{7}$ The PAIGC's diplomatic enterprise had the communist states as one of its primary targets (Lopes 2012: 89). Soon after arriving in Conakry, on May 11, Cabral met with other anti-colonial nationalists from different Portuguese African colonies to discuss a "study trip to China." In a subsequent meeting, held on May 22, the same group strategized about visits to foreign embassies in Conakry as well as to the Political Bureau of the PDG, the ruling party of Guinea. The group decided that a small delegation would approach the embassies of USSR and China. ${ }^{9}$

One reason for this focus on the communist bloc had to do with their representation in Conakry. Given the turbulent process of decolonization in Guinea, the communist bloc showed great willingness to recognize the new state. As a consequence, the diplomatic landscape in Conakry in the late 1950s and early 1960s was clearly marked by the communist states from Eastern Europe and Asia (Attwood 1967: 33, Morrow 1968: 127-128, Schmidt 2007: 172). In the early 1960s, there were more embassies from the communist bloc than from the Western states. As soon as he set foot in Conakry, Cabral embarked on an exhausting and arduous shoe-leather diplomacy campaign towards foreign chancelleries in Conakry. A typical dictionary definition of the term 'shoeleather' is the "wear on shoes through walking" (www.oed.com). The term, as such, involves walking from place to place to engage in direct communication with others, rather than staying back in an office to develop contacts. Here I use shoeleather diplomacy to refer to the fact that Cabral and other party leaders physically and constantly went from one place to another, from embassies, residencies of foreign officials to other venues, where they met foreign officials and diplomats and/or attended social gatherings held at these embassies and/or the residencies of embassy officials. Through shoe-leather diplomacy, Cabral created opportunity to talk and exchange ideas with members of diplomatic corps, statesmen, and/or foreign intelligence officials. ${ }^{10}$ 
14 Another important reason for the diplomatic proximity to the communist states had to do with the foreign policy position of Western European states. Major European states such as France and the United Kingdom were traditional allies of Portugal. Moreover, French and British decolonization in the early 1960s did not alter their scope and levels of involvement in Africa (Rouvez 1994). Both British and French interests in Africa maintained influence and neo-colonial control in their erstwhile colonies, which aligned very well with the interests of Portugal. Furthermore, those European states shared similar political and security interests with Portugal, as they were the major suppliers of weaponry to the Portuguese armed forces and their intelligence agencies were on good terms (Lopes 2014). In the early 1960s, the PAIGC leadership knew that reaching out to the Western states was a waste of time and resources that could not bring any real advantages to the struggle. Outreach to the Western states, chiefly the Nordic European states, was part of a strategy that the PAIGC would develop later in 1969 (Soiri and Peltola 1999, Sellström 2003: 17-18, Lopes 2012: 137).

Ideology facilitated the interaction between the PAIGC and the communist states. The politics of Cold War brought the communist states to the same side of the national liberation movements; both claimed to fight Western imperialism. It is important to note that neither Cabral nor the PAIGC could be classified as Marxists; yet, in many ways, Marxism informed the organization's political work. Cabral's political analyses relied on the Marxist class-based approach and his political language included Marxist vocabulary. Additionally, there was a confluence of ideological precepts that linked the PAIGC to the communist states: anti-imperialism, anti-colonialism, the legitimacy of national liberation struggle, and internationalism were at the heart of their political discourse (Telepneva 2015). Furthermore, since the late 1950s, the Soviet Union and its Eastern European satellites adopted a foreign policy that emphasized Leninist internationalism and the duty of these states to provide necessary assistance to colonial peoples in their quest for liberation (Beck 1963: 404, Casey 1982: 156-157). The death of Joseph Stalin in 1953 and the subsequent rise of Nikita Khrushchev paved the way to a change of Soviet foreign policy towards the people and territories of the European colonies. Unlike Stalin, Khrushchev grounded Soviet Union diplomacy in the Third World in terms of support to the national liberation movements. As noted by Roger E. Kanet, “Stalin's successor, Nikita Khrushchev, rediscovered Lenin's argument that the peoples of the colonial world represented de facto allies of the proletariat and of the first proletarian state, the Soviet Union" (2006: 334). Similarly, Francis Casey (1982: 152) argues that the support for national liberation movement dates back to the Leninist period, as it was a core principle developed in the framework of the Comintern, the Soviet-controlled organization founded in 1919 to support communist and anticolonial political organizations around the world.

16 As stated earlier, the Soviet Union was a prime target of the PAIGC's diplomatic offensive. The mission led by Mario Pinto de Andrade, the founding leader of the People's Movement for the Liberation of Angola (MPLA), to the Soviet embassy in Conakry did not bear any fruit for the PAIGC. One of the earliest documents attesting to the contact between the PAIGC and Soviet Union is a cable sent by Amílcar Cabral from Moscow on August 4, 1960, to his brother, Luís Cabral. In the cable, Cabral was enthusiastic about how he was received and seemed to be quite optimistic about possible cooperation and assistance from the Soviet Union. ${ }^{11}$ Cabral also met some leaders of the Soviet Afro-Asiatic Peoples Solidarity Committee. 
17 By September 1960, the links with the Soviet Afro-Asiatic Peoples Solidarity Committee had strengthened, as a September 26, 1960, letter from Cabral to one its representative, Valentin Ivanov, attests. The fact that Cabral addressed Ivanov as 'informal you' (" $t u$ " in original French) illustrates that the two had previous engagements and had reached a level of political friendship. In the letter, Cabral focused on two main points. First, he argued for the need to visit the Soviet Union, noting that such a trip would be "useful to our liberation struggle and contribute to reinforcing the friendship between the great Soviet people and our people." ${ }^{12}$ By this time, Cabral understood that any real assistance and cooperation could not come from the embassy in Conakry. His soliciting a trip to the Soviet Union could be part of a strategy to meet with officials with decision-making power. The letter also focused on scholarships promised to the then extinct Movement for the Liberation of the Territories under Portuguese Domination (MLTDP). ${ }^{13}$ Cabral noted that there were only three organizations that could make claims on the scholarships, namely the PAIGC, MLGC, and African Revolutionary Front for the National Independence of the Portuguese Colonies (FRAIN). ${ }^{14}$ Cabral also complained that the Soviet embassy in Conakry insisted on dealing with two BissauGuineans, Luís da Silva and Belarmino Gomes, who had been expelled from the organization. The missive sent by Cabral received a response more than a month later from Lev Soukhanov, who was responsible for the territories under Portuguese domination within the Soviet Afro-Asian Solidarity Committee. Soukhanov asked Cabral for written material on the socio-economic and political conditions of African territories under Portuguese domination. He agreed with Cabral's views on Belarmino Gomes and Luís da Silva. ${ }^{15}$ A week later, on November 10, 1960, the Soviet Committee, through its Secretary-General, M. Bakhitov, reached out to Cabral to formalize the invitation for a visit to Soviet Union. ${ }^{16}$

In March 1961, Amílcar Cabral traveled to Moscow, where he stayed for two weeks. The trip strengthened the political links with the Soviet Committee, though Cabral returned empty-handed to Conakry. Mustafah Dhada (1993: 157) asserts that the PAIGC failed to secure any concrete aid from Soviet Union because of the links it had with China. Telepneva (2015: 89) rejects this claim and makes a persuasive argument that the Soviets did not provide assistance to the PAIGC because they had outsourced the assistance to the Czechoslovaks. Yet, the visit to the country also served to develop further relations with other Soviet mass organizations, particularly the Committee of the Soviet Youth Organizations and the Soviet Women's Committee. While these organizations did not exercise any policy-making power - and were not central organisms in the Soviet political system - they aided the PAIGC in three important ways. First, these mass organizations were important channels through which the PAIGC propaganda and information could be disseminated to different sectors of Soviet society, including the elite. Second, political contacts developed with these organizations eventually facilitated the contacts with the Communist Party of Soviet Union (CPSU). Given their subordinate status within the Soviet political system, these organizations sent reports about their activities to the CPSU. Their positive reporting on the political works of the PAIGC and its leadership likely opened doors to the CPSU. Third, these organizations were key partners in providing education cooperation to the PAIGC. Scholarships provided by these organizations allowed the PAIGC to send many of its cadre to institutions of technical and higher education throughout the Soviet Union. 

perception of Amílcar Cabral and the PAIGC had changed. Given the rigidity of the Soviet political system, characterized by a stiff hierarchy of political organizations, to be hosted by a bureaucrat of the CPSU was a sign of political significance. Thus, unlike the previous visit, during which he was hosted by the Soviet Committee, during the February 1962 visit Cabral had a bureaucrat of the CPSU as his host and guide (Telepneva 2015: 93). Like the previous visit, Cabral failed to persuade the Soviets and did not get any military assistance from them (Dhada 1993: 13). Given the constant exchange of information with Czechoslovakia, the Soviets most likely did not find the need to provide additional military assistance to the PAIGC.

In January 1963, the PAIGC launched the armed struggle for national liberation in southern Guinea-Bissau. During that year, with the exception of a short trip to France and Czechoslovakia, Cabral did not travel outside the African continent (Ibid.: 172-173). Most of the diplomatic activity centered on letter writing and meetings with officials from the embassies. During this period, congratulatory diplomacy became an important method of political work of the party. In November 1963, Cabral dispatched two letters, one to the Soviet Committee and the other to the Soviet leader, Nikita Khrushchev, congratulating them on the anniversary of the October Revolution. While the Soviets did not deliver any military assistance to the PAIGC, they provided assistance in other critical areas, ranging from technical and professional training, propaganda support to financial aid and grants. Moreover, the relationship between the PAIGC and the Soviet Union incrementally developed during and after 1964; with the new phase of the armed struggle, the Soviets became more involved in the liberation war.

the period of 1960-1963, political contacts between PAIGC and Soviet Union were limited to the embassy in Conakry and the Soviet Committee and other mass organizations. There are no records that the leadership of the CPSU ever replied to the letters and other written messages sent by the PAIGC. In fact, in the first few years of the 1960s, the PAIGC did not attract attention from the top echelon of the Soviet political elite. For instance, Cabral's letters addressed to Nikita Khrushchev, the highest leader of the Soviet regime, were not answered (a situation that would change in the mid- to the late-1960s). ${ }^{17}$

Unlike Soviet Union, Czechoslovakia was very receptive to the pleas of the PAIGC, and the Eastern European country was one of the first states to fully embrace the PAIGC political cause, thereby becoming a key and strategic partner. The PAIGC approached the Czechoslovak embassy in Conakry sometime between June and September 1960, when Cabral met embassy officials, particularly Miroslav Alter, an agent of the Czechoslovak intelligence (StB). Cabral's political persona, charm, and his capacity to provide complex and yet clear analyses of African politics, had a profound and lasting effect on Alter. In fact, Alter seriously invested in Cabral and, in time, the two developed a mutually advantageous relationship (Telepneva 2015: 59, Muehlenbeck 2016: 105). The PAIGC scored a major diplomatic victory when, in March 1961, the Czechoslovak Minister of Interior, Rudolph Barak, met Amílcar Cabral and Aristides Pereira. The meeting, arranged by Alter, provided a boost in the morale of the PAIGC and also led to concrete military assistance on the part of Czechoslovakia (Telepneva 2015: 87). On August 1, 1961, the Politburo of the Czechoslovakia Communist Party decided to send military assistance to the PAIGC (Ibid.: 89). As part of the deal, the 
leadership of the PAIGC had to work with the government of the Republic of Guinea on the process of receiving the military cargo (Ibid.: 86, Lopes 2012: 97).

By the third trimester of 1961, Czechoslovakia strengthened its educational cooperation with the PAIGC. ${ }^{18}$ As in the case of the Soviet Union, the PAIGC invested in a myriad of relationships with Czechoslovak political organizations. One of the organizations with which the party cultivated robust political relations was the Central Council of Trade Unions. This organization played an important role in the provision of technical training to the cadres of the party, chiefly in the realms of trade unionism and political organization. ${ }^{19}$

Cabral, accompanied by his comrade and brother Luís Cabral, returned to Czechoslovakia in October 1963, several months after the war broke out in GuineaBissau. The objective of the mission was to request additional military assistance as well as a military advisor. The leadership of the Czechoslovak Communist Party granted the request for two main reasons: the fact that the PAIGC was "a serious movement, which reaches concrete achievements in the fight against colonialism and due to good relations between PAIGC and Czechoslovakia" (Muehlenbeck 2016: 106). The relationship between the PAIGC and Czechoslovakia strengthened as Cabral became a valuable source of information for the StB on matters pertaining to Portuguese colonialism in Africa and African affairs in general (Telepneva 2015: 90). Cabral understood that such a relationship with the StB could be beneficial to the party and the struggle. His political realism dictated such a quid pro quo relationship with the Czechoslovak intelligence.

The case of the PRC is unique, as the country developed its Africa policy during the famous 1955 Bandung Conference (El-Khawas 1973: 24). As part of its diplomatic strategy to seek global visibility and circumvent isolation, China's foreign policy towards Africa emphasized not only the need to assist the maintenance of recently-won national independence but also to cooperate with organizations fighting for independence. When Guinea became independent in 1958, China not only recognized the new state but promptly extended the needed assistance. The Chinese embassy in Conakry soon became a pivotal tool in carrying out the strategy of developing contacts with African nationalists (Ibid.).

The Chinese embassy became a focal point of Cabral's shoe-leather diplomacy in the years of 1960 and 1961. In the archives of the PAIGC, there are many visit cards from officials from the Chinese embassy, mostly likely handed in directly when initial contacts were first established. At the same time, the Chinese embassy in Conakry was an important platform for political indoctrination. For instance, in 1961, the embassy presented propaganda films and PAIGC members were among those attending the events. The Chinese were open to the African nationalists and the contacts with the embassy proved to be useful.

As noted above, the PRC was one of the first targets of the PAIGC and Cabral's diplomatic incursion in Conakry. As early as May 11, 1960, Cabral, along with other African nationalists from other then Portuguese colonies, planned and eventually met with officials from the Chinese embassy. In early August, the Chinese government invited two delegations to visit the country in a "study and solidarity visit." The MPLA delegation was led by Viriato da Cruz and Cabral led the PAIGC delegation (Friedman 2015: 54). Cabral departed to China on July 28, 1960, and arrived on August 5, 1960. Cabral sojourned for a month in China and developed a number of important political 
contacts. In the Chinese capital, the PAIGC delegation met officials of two Chinese institutions: the Chinese Committee of the Afro-Asian People's Solidarity Organization (AAPSO) and the People's Institute of Foreign Affairs.

After his return to Conakry on September 17, Cabral reported to Luís Cabral that the trip to China was a "long trip that was very good, though packed with work." The trip paid off politically since, in Cabral's own words, "we have more friends and we are stronger for the march, on the path of liberation of our people." ${ }^{20}$ China revealed its willingness to support the organization materially, morally and politically, by offering military training to a small group of PAIGC members in the Nanjing Military Academy. ${ }^{21}$ The level of commitment in supporting the cause of the PAIGC became evident when these PAIGC cadres met the supreme leader of the country, Mao Zedong. This situation contrasts with the case of the Soviet Union, where the PAIGC could not attract any attention from the top echelon of the Communist Party.

The trip to China and the subsequent direct assistance to the PAIGC further strengthened the cooperation ties between PAIGC and China. Other Chinese political institutions, such as the Federation of Chinese Trade Unions, the National Federation of Students of China, and the Chinese-African Peoples Friendship Association, and subsidiary organizations of the PAIGC, such as the National Union of Workers of Guinea-Bissau (UNTG), also became engaged in the web of relationships and exchange of communication. For instance, in January 1963, Aristides Pereira, writing on behalf of the Political Bureau of the PAIGC, thanked the Federation of Chinese Trade Unions for the gift of a white stamp with the symbols of the party made by the workers from Shanghai. ${ }^{22}$

In the first few years of the 1960s, China was undoubtedly a key partner of the PAIGC. China was the first state to respond to the appeals made by the PAIGC, providing financial assistance and needed military training to the cadres of the PAIGC. In order to maintain the level of commitment of China, the PAIGC invested strongly in a congratulatory diplomacy: from late 1960 to January 1964, the PAIGC dispatched a total of thirteen messages, to different Chinese audiences, celebrating national days and/or major events. While relationship with China and the PAIGC took a different course in the second half of the 1960s, in the period under study Cabral prudently cultivated and maintained strong links with the Chinese communists (Sousa 2020).

31 The Soviet Union, Czechoslovakia, and the PRC were not the only partners of the PAIGC in the period under study. While the levels of engagement were not the same among all the states that made up the bloc, in the years under analysis, countries such as Poland, Bulgaria, German Democratic Republic, and Romania engaged minimally with the PAIGC. Support from these communist states was in terms of propaganda support and scholarships for technical training and access to higher education.

The case of Cuba is interesting. It was not until after 1964 that Cuba began to assist the PAIGC in the national liberation struggle. By the end of the struggle, Cuba became one of the strongest backers of the PAIGC, providing military advisers and other technicians who fought along with the PAIGC (Laranjeiro 2019). Piero Gleijeses (2002) argues that the contacts between the PAIGC and Cuba began in early 1963. However, as early as January 1,1962 , the PAIGC contacted Cuban authorities when Cabral wrote to the leader of the Revolutionary Council of the Socialist Republic of Cuba, Fidel Castro, congratulating Cuba on the third anniversary of "the victory of the Cuban people against imperialism's reactionary and lackey forces" and, at the same time, pleading for 
Cuba's "combative solidarity." 23 At the time, Cuban leaders were too preoccupied with the survival of the regime to undertake such political commitment across the continent.

In sum, the communist bloc was a main source of backing for the PAIGC. Support from these states can be grouped into eight different categories: propaganda support, political/diplomatic support, professional/academic training, humanitarian assistance, financial aid/grants, military training, arms supply, and military advisors on the spot (Golan 1987). Propaganda support refers to the use of the state media and other channels to disseminate, both domestically and internationally, the materials and information either provided by or friendly to the PAIGC. Political and diplomatic support denotes endorsement of the organization and/its objectives in the main arenas of global politics, particularly the United Nations. The other criterion under analysis is professional and academic training, which includes the granting of scholarships to the cadres of the PAIGC to attend institutions of technical, professional, or higher education. Humanitarian assistance and financial aid/grants refers to assistance inkind and in monetary terms, respectively. Military assistance, an important criterion, can be subdivided into three main subcategories. Military training is the acceptance of the PAIGC military cadres in the various military academies. Arms supply is the direct transference of weaponry to the PAICG, and, lastly, military advisors on the spot refers to army instructors sent to work with the PAIGC, either in the headquarters or inside Guinea-Bissau, for the goal of assisting with tactical and weapon training of the military rank-and-file. Aid from each of these categories can be further described in terms of its intensity: high, low, or no commitment (see table 1).

Table 1. Types and intensity of support from the communist bloc, May 1960-February 1964

\begin{tabular}{|c|c|c|c|c|}
\hline Types of assistance & USSR & China & Czechoslovakia & Others \\
\hline Propaganda Support & $\mathrm{x}$ & $\mathrm{x}$ & $\mathrm{x}$ & $\mathrm{x}$ \\
\hline Political Diplomatic Support & 0 & o & o & o \\
\hline Professional/Academic Training & $\mathrm{x}$ & $\mathrm{x}$ & $\mathrm{x}$ & $\mathrm{x}$ \\
\hline Humanitarian Assistance & 0 & o & o & o \\
\hline Financial Aid/Grants & $\mathrm{x}$ & $\mathrm{x}$ & $\mathrm{x}$ & 0 \\
\hline Military Training & - & $\mathrm{x}$ & $\mathrm{x}$ & - \\
\hline Arms Supply & - & - & $\mathrm{x}$ & - \\
\hline Military Advisors on the Spot & - & - & $\mathrm{x}$ & - \\
\hline
\end{tabular}

x: high intensity support o: low intensity support

Adapted from Golan (1987).

In the first four years of the 1960s, Czechoslovakia was by far the state that committed the most support to the PAIGC: with the exception of political- diplomatic and humanitarian assistance, the country provided high-intensity aid in all other 
categories. The level of the Czechoslovakian commitment was such that the country was probably the first state to send military advisers to the field to assist the PAIGC in its struggle against the Portuguese colonial state (Muehlenbeck 2016: 106). The Soviet Union, on the other hand, limited its assistance to the PAIGC to the areas of propaganda support, professional training, and financial aid/grants.

\section{On Congratulatory Diplomacy}

It was in Conakry that the PAIGC first developed their diplomatic enterprise. In the initial stage, during the years of 1960 and 1961, shoe-leather diplomacy was the main method of engagement and establishing rapport with foreign chancelleries, particularly the embassies from the communist states. By the end of 1960, and particularly during 1961 and 1962, the PAIGC embarked upon what can be called congratulatory diplomacy, a strategy of political and diplomatic engagement and consolidation with foreign governments. The main method of congratulatory diplomacy was written political communication, either a formal letter or a cable telegram. These written messages, dispatched from the PAIGC offices to foreign governments, had a central message: to assist celebrating and/or congratulating them on the anniversary of a national day or a major event.

Cabral and the leaders of the PAIGC understood the logic of the modern nation-state. National days are important devices in fostering and stimulating national identity, as they "give the nation a heartbeat - a calendric rhythm of self-awareness and pride" (Salmond 2009: xiii). David McCrone and Gayle McPherson (2009: 1) make the compelling argument that national days constitute "commemorative devices in time and place for reinforcing national identity." By invoking national days in its political communications, the PAIGC sought to capture the attention of the targeted state by appealing to the national pride that national days bring. Congratulatory diplomacy did not focus solely on national days. The PAIGC also dispatched political communications that stressed and celebrated major political events (such as the realization of the party congress, as in the case of the Soviet Union), new year messages, or major accomplishments made by the targeted state (such as the voyage made by the Soviet astronaut Yuri Gagarin). ${ }^{24}$ In essence, congratulatory diplomacy was a method of maintaining open channels of communication as well as strengthening the rapport with the target state. The act of sending congratulations and best wishes regarding a national day or a major feat reinforced linkages between the PAIGC and the foreign state. It became an important building block of iteration of political relations, increasing, therefore, prospects for further cooperation.

These congratulatory notes also included requests for support to the cause of national liberation struggle. To make this point, I will focus on two examples. On October 1, 1961, Cabral wrote to the President of the Chinese Committee of the AAPSO, congratulating them, "in the name of the peoples from 'Portuguese' Guinea and the islands of Cabo Verde, and in the name of our Party," on the twelfth anniversary of the foundation of the PRC. While focusing on highlighting this national day in China, the letter was also the medium for reinforcing the links between "Chinese people and our peoples." ${ }^{25}$ In October 1961, Luís Cabral, a member of the Political Bureau of the PAIGC wrote to the CPSU on the occasion of the realization of its 22nd Congress. The letter, consisting of five main paragraphs, salutes and congratulates the Communist Party for 
its meeting as well as for the historical feats it had accomplished in the past. In the last paragraph of the letter, Luís Cabral went on to insist on the need for "concrete assistance." ${ }^{26}$

The states of the communist bloc were a main target of the PAIGC's congratulatory diplomacy. From late 1960 to February 1964, the PAIGC dispatched a total of twenty-one letters and cables to the Soviet Union, Czechoslovakia, and the PRC (see table 2). It is important to note that in the period under study, the PAIGC's congratulatory diplomacy target was China, more than any other state. Given the fact that China was one of the first to respond to the requests made by the PAIGC, the strategy meant to reinforce and strengthen the links developed with the Asian country.

Table 2. Dispatches from the PAIGC. Congratulatory diplomacy

\begin{tabular}{|l|l|l|l|}
\hline Country & National Day & New Year & Other dates \\
\hline China & 7 & 1 & 5 \\
\hline USSR & 3 & 1 & 1 \\
\hline Czechoslovakia & 1 & 1 & 1 \\
\hline Others, Communist Bloc & 4 & - & - \\
\hline Total & 15 & 3 & 7 \\
\hline
\end{tabular}

Source: Casa Comum, Arquivo Amílcar Cabral (www.casacomum.org).

\section{Conclusion}

The PAIGC, initially founded as a political party, evolved to become a multidimensional liberation movement, engaged in different political arenas, including that of diplomacy and foreign relations. Apart from fulfilling other political roles, the PAIGC ultimately grew into a well-organized diplomatic chancellery, developing and maintaining a complex web of diplomatic relations with states and non-state actors from different regions and continents.

This paper has focused on three main points regarding the diplomatic strategies and practice of the PAIGC. The first point is that the leadership of the PAIGC, particularly its Secretary-General, Amílcar Cabral, posited diplomacy as a central element in the national liberation struggle. For this reason, as early as May 1960, when Cabral moved to Conakry to set up the Secretariat General, the party began to develop a plan to reach out foreign chancelleries, particularly those from the communist bloc.

The second main point that the paper addresses is the development of a shoe-leather diplomacy in the first years of the 1960s. Once in Conakry, a primary focus of the PAIGC was to approach foreign chancelleries based there. This diplomatic scheme entailed meetings with foreign officials and embassy officers in different locations of the city. Through these initial contacts, the PAIGC was able to develop strong alliances with a number of states, particularly Czechoslovakia, the Soviet Union, and the PRC. 


\section{BIBLIOGRAPHY}

Attwood, W. 1967, The Reds and the Blacks. A Personal Adventure, New York, Harper \& Row.

Beck, C. F. 1963, “Czechoslovakia's penetration of Africa, 1955-1962”, World Politics, 15 (3): 403-416.

Cabral, A. 1974, Return to the source; selected speeches, New York, Monthly Review Press.

Cabral, A. 1979, Unity and struggle: Speeches and writings. Texts selected by the PAIGC, Transl. by Michael Wolfers, New York, Monthly Review Press.

Casey, F. M. 1982, "Soviet strategy for the third world: wars of national liberation", The Journal of East Asian Affairs, 2 (1): 152-169.

Chabal, P. 2003, Amilcar Cabral: Revolutionary Leadership and People's War, Trenton, New Jersey, Africa World Press.

Chilcote, R. 1972, Emerging Nationalism in Portuguese Africa: Documents, California, Hoover Institution Press.

Dhada, M. 1993, Warriors at work: how Guinea was really set free, Niwot, Colorado, University Press of Colorado.

Dhada, M. 1995, “Guinea-Bissau's Diplomacy and Liberation Struggle”, Portuguese Studies Review, 1 (4): 20-39.

El-Khawas, M. A. 1973, “China's Changing Policies in Africa”, Issue: A Journal of Opinion, 3 (1): 24-28.

Fistein, D. 2014, “The Diplomatic Achievements of Amílcar Cabral: A Case Study of Effective Leadership in a Small African State", in B. G. Jallow ed., Leadership in Colonial Africa. Disruption of Traditional Frameworks and Patterns, New York, Palgrave Macmillan: 69-100.

Friedman, J. 2015, Shadow Cold War: the Sino-Soviet Competition for the Third World, Chapel Hill, University of North Carolina Press.

Gleijeses, P. 2002, Conflicting Missions: Havana, Washington, and Africa, 1959-1976, Chapel Hill, University of North Carolina Press. 
Godinho Gomes, P. 2010, Os fundamentos de uma nova sociedade. O PAIGC e a luta armada na GuinéBissau, 1963-1973: organização do Estado e relacões internacionais, Torino, L'Harmattan Italia.

Golan, G. 1987, "Moscow and Third World National Liberation Movements: The Soviet Role", Journal of International Affairs, 40 (2): 303-324.

Kanet, R. E. 2006, “The Superpower Quest for Empire: The Cold War and Soviet Support for 'Wars of National Liberation'”, Cold War History, 6 (3): 331-352. DOI: 10.1080/14682740600795469.

Laranjeiro C. 2019, “The Cuban Revolution and the Liberation Struggle in Guinea- Bissau: Images, Imaginings, Expectations and Experiences", The International History Review. DOI: 10.1080/07075332.2019.1706185.

Lopes, J. V. 2012, Aristides Pereira: minha vida, nossa história, Praia, Spleen.

Lopes, R. 2014, Germany and the Portuguese Dictatorship 1968-1974. Between Cold War and Colonialism, London, Palgrave McMillan.

McCrone, D. \& McPherson, G. 2009, National days: constructing and mobilising national identity, Houndmills, Basingstoke, Palgrave Macmillan.

Morrow, J. H. 1968, First American Ambassador to Guinea, New Brunswick, New Jersey, Rutgers University Press.

Muehlenbeck, P. E. 2016, Czechoslovakia in Africa, 1945-1968, New York, Palgrave Macmillan.

Reis, B. C. 2013, "Portugal and the UN: A Rouge State Resisting the Norm of Decolonization (1956-1974)", Portuguese Studies, 29 (2): 251-276.

Rouvez, A. 1994, Disconsolate Empires: French, British and Belgian Military Involvement in Post-Colonial Sub-Saharan Africa, Lanham, New York, University Press of America.

Salmond, A. 2009, "Preface”, in D. McCrone \& G. McPherson eds., National days: constructing and mobilising national identity, Houndmills, Basingstoke, Palgrave Macmillan: xiii-xiv.

Santos, A. A. 2017, A Organização das Nações Unidas e a Questão Colonial Portuguesa: 1960-1974, Lisboa, Instituto de Defesa Nacional.

Schmidt, E. 2007, Cold War and Decolonization in Guinea, 1946-1958, Athens, Ohio, Ohio University Press.

Sellström T. 2003, Sweden and National Liberation in Southern Africa, Uppsala, Nordiska Afrikainstitutet.

Shubin, V. 2009, The hot 'cold war': the USSR in Southern Africa, Scottsville, University of KwaZuluNatal Press.

Silva, A. E. D. 1995, “O litígio entre Portugal e a ONU (1960-1974)”, Análise Social, XXX (130): 5-50.

Soiri, I. \& Peltola, P. 1999, Finland and National Liberation in Southern Africa, Uppsala, Nordiska Afrikainstitutet.

Sousa, J. S. 2016, Amilcar Cabral (1924-1973): Vida e Morte de um Revolucionário Africano, Coimbra, Edição do Autor.

Sousa, J. S. 2020, "Amilcar Cabral, the PAIGC and the Relations with China at the Time of the SinoSoviet Split and of Anti-Colonialism. Discourses and Praxis", The International History Review. DOI: 10.1080/07075332.2019.1695139.

Telepneva, N. 2015, Our Sacred Duty: The Soviet Union, the Liberation Movements in the Portuguese Colonies, and the Cold War, 1961-1975, PhD Thesis, London School of Economics. 


\section{NOTES}

1. For a list of Cabo Verdean and Bissau-Guinean anticolonial organizations based in Dakar in 1962, see the list compiled by the PAIGC. Casa Comum, Fundação Mário Soares (FMS), Documentos Amílcar Cabral (DAC) (1962), Movimentos sediados em Dakar, accessed on 27 July 2019, http://hdl.handle.net/11002/fms_dc_39678.

2. Casa Comum, FMS, DAC - Iva Cabral (1960), Proclamação do MLGCV, accessed on 1 January 2020, http://hdl.handle.net/11002/fms_dc_42827.

3. Casa Comum, FMS, DAC (1961), Proclamação da FUL/Carta da FUL, accessed on 1 January 2020, http://hdl.handle.net/11002/fms_dc_42870.

4. Casa Comum, FMS, DAC (1960), Comunicado do MLG enviado ao PDG, accessed on 27 July 2019, http://hdl.handle.net/11002/fms_dc_39631. The same organization took similar action towards the Czechoslovak embassy. For the latter, see Casa Comum, FMS, DAC (1960), Letter from the Secretary-General Adjunct of the MLG to the Ambassador of Czechoslovakia in Conakry, December 1960, accessed on 27 July 2019, http://hdl.handle.net/11002/fms_dc_39502.

5. Casa Comum, FMS, DAC (1962), Letter from Amílcar Cabral to the Ambassador of the Republic of Algeria in Conakry, August 13, 1962, accessed on 27 July 2019, http://hdl.handle.net/11002/ fms_dc_37689.

6. See, for instance, Casa Comum, FMS, DAC (1962), Letter from Amílcar Cabral to Fidel Castro, January 1, 1962, accessed on 4 February 2020, http://hdl.handle.net/11002/fms_dc_39318.

7. While the term 'communist bloc' gives the appearance of monolithism and homogeneity, in reality the bloc was ideologically, geographically, and economically diverse. In spite of different interpretations of scientific socialism, the states shared key ideological precepts of Marxism. Geographically, these states ranged from Eastern Europe to East Asia (and later in the 1960s, the case of Cuba in the Caribbean).

8. Casa Comum, FMS, DAC (1960), Reunião de 11 de Maio de 1960, accessed on 27 July 2019, http:// hdl.handle.net/11002/fms_dc_42546.

9. Casa Comum, FMS, DAC (1960), Reunião de 22 de Maio de 1960 - Domingo, accessed on 27 July 2019, http://hdl.handle.net/11002/fms_dc_41276.

10. As for an example, see Casa Comum, FMS, DAC (1960), Invitation from Ilija Topaloski, Ambassador of the People's Republic of Yugoslavia to Amílcar Cabral, November 1960, accessed on 27 July 2019, http://hdl.handle.net/11002/fms_dc_39269. See also Casa Comum, FMS, DAC, Business Card from Jan Miaskowski, Attaché of the People's Republic of Poland to SecretaryGeneral Amílcar Cabral, accessed on 18 August 2019, http://hdl.handle.net/11002/fms_dc_38070. 11. Casa Comum, FMS, DAC (1960), Cable from Amílcar Cabral to Luís Cabral, August 4, 1960, accessed on 27 July 2019, http://hdl.handle.net/11002/fms_dc_39033.

12. Casa Comum, FMS, DAC (1960), Letter from Amílcar Cabral to Valentin Ivanov, September 26, 1960, accessed on 27 July 2019, http://hdl.handle.net/11002/fms_dc_39194.

13. The MLTDP was a Conakry-based political organization created by Africans from different Portuguese colonies, namely, by Hugo Menezes, a native of Sao Tome and Principe. The organization was disbanded by its members on June 29, 1960. For more on the subject, see Casa Comum, FMS, DAC, MLTDP (1960), Cópia da Resolução geral da Assembleia Geral Extraordinária do MLTDP, accessed on 8 January 2020, http://hdl.handle.net/11002/fms_dc_42810.

14. The Movement for the Liberation of Guinea-Bissau and Cabo Verde (MLGC) was a front created in Conakry in 1960 that brought together the PAIGC and other Bissau-Guinean and Cabo Verdean nationalists in June 1960. The African Revolutionary Front for the National Independence of the Portuguese Colonies (FRAIN) was a trans-territorial and coordinating committee made up of the PAIGC and the Angolan People's Movement for Liberation of Angola (MPLA). 
15. Casa Comum, FMS, DAC (1960), Letter from Lev Soukhanov to Amílcar Cabral, November 4, 1960, accessed on 27 July 2019, http://hdl.handle.net/11002/fms_dc_39201.

16. Casa Comum, FMS, DAC (1960), Letter from M. Bakhitov to Amílcar Cabral, November 10, 1960, accessed on 27 July 2019, http://hdl.handle.net/11002/fms_dc_38864.

17. For instance, in mid-1962, following the massive onslaught of anticolonial nationalists in Bissau, carried out by the infamous political police, the International Police for the Defense of the State (PIDE), in which the President of the Political Bureau of the PAIGC, Rafael Barbosa, was detained, Cabral dispatched a cable to Khrushchev requesting assistance in resolving this issue. There are no written records that Khrushchev ever responded to the cable. See Casa Comum, FMS, DAC (1962), Cable from Amílcar Cabral to Nikita Khrushchev, 1962, accessed on 27 July 2019, http://hdl.handle.net/11002/fms_dc_39205. This situation contrasts with the case of Angola. For instance, the pleas made by Mario Pinto de Andrade, the leader of the MPLA, deserved a public response from Khrushchev on the regime's official newspaper, Pravda, in its June 16, 1961 edition. For more on this, see Shubin (2009: 9).

18. Casa Comum, FMS, DAC (1961), Acta da Reunião do Secretariado do PAIGC, September 20, 1961, accessed on 28 July 2019, http://hdl.handle.net/11002/fms_dc_34129.

19. Casa Comum, FMS, DAC (1961), Letter from Amilcar Cabral, Secretário Geral do PAIGC, to Secretário do Conselho Central dos Sindicatos da Checoslováquia, May 11, 1961, accessed on 28 July 2019, http:// hdl.handle.net/11002/fms_dc_39465.

20. Casa Comum, FMS, DAC (1960), Letter from Amílcar Cabral to Luís Cabral, 1960, accessed on 12 July 2019, http://hdl.handle.net/11002/fms_dc_38858.

21. Casa Comum, FMS, DAC, Reunião com membros do Comité Director do MLGCV (em casa de Turpin) e reunião da Assembleia Geral do MLGCV, com Amilcar Cabral, accessed on 12 July 2019, http:// hdl.handle.net/11002/fms_dc_42837.

22. Casa Comum, FMS, DAC (1963), Letter from Aristides Pereira to The Chinese Federation of Trade Unions, January 15, 1963, accessed July 12, 2019, http://hdl.handle.net/11002/ fms_dc_36063.

23. Casa Comum, FMS, DAC (1962), Letter from Amílcar Cabral to Fidel Castro, January 1, 1962, accessed on 28 July 2019, http://hdl.handle.net/11002/fms_dc_39318.

24. Casa Comum, FMS, DAC (1961), Cable from Amílcar Cabral to Soviet Committee of the AAPSO, April 13, 1961, accessed on 28 July 2019, http://hdl.handle.net/11002/fms_dc_34189.

25. Casa Comum, FMS, DAC (1961), Letter from Amílcar Cabral, Secretary-General of the PAIGC to the President of Chinese Committee of Afro-Asiatic Solidarity, October 1, 1961, accessed on 28 July 2019, http://hdl.handle.net/11002/fms_dc_38579.

26. Casa Comum, FMS, DAC (1961), Message to the 22nd Congress of the Communist Party of Soviet Union by Luís Cabral, October 1961, accessed on 28 July 2019, http://hdl.handle.net/ 11002/fms_dc_41428.

\section{ABSTRACTS}

Through a critical analysis of primary and secondary sources, this paper reconstitutes the PAIGC's main strategies and processes of diplomatic communication and engagement towards the states of the communist bloc, which were the main backers of the liberation enterprise. The paper argues that the PAIGC's diplomacy in its first four years rested on two strategies. First, it 
consisted of "shoe-leather" diplomacy, as its leaders regularly attended public spaces frequented by foreign diplomats and embassy officials. Second, it involved a congratulatory diplomacy, the initiating of diplomatic communication with foreign governments by deliberately using the recipient country's national days as the key motive for the message.

À travers une analyse critique des sources primaires et secondaires, cet article reconstitue les principales stratégies et processus de communication diplomatique et d'engagement du PAIGC vis-à-vis des États du bloc communiste, qui ont été les principaux soutiens de l'entreprise de libération. L'article soutient que la diplomatie du PAIGC au cours de ses quatre premières années reposait sur deux stratégies. Premièrement, il s'agissait d'une "shoe-leather diplomacy ", car ses dirigeants ont visité régulièrement des lieux publics fréquentés par des diplomates étrangers et des représentants de l'ambassade. Deuxièmement, il s'agissait d'une diplomatie congratulatoire consistant à établir une communication diplomatique avec des gouvernements étrangers en utilisant délibérément les fêtes nationales des pays destinataires comme motif du message.

Através de uma análise crítica de fontes primárias e secundárias, o presente artigo reconstitui as principais estratégias e processos de comunicação diplomática e engajamento do PAIGC para com os estados do bloco comunista, grupo esse que foi um dos que mais apoiaram a luta de libertação nacional travada pelo PAIGC. O artigo argumenta que a diplomacia do PAIGC nos primeiros quatro anos da década de sessenta se baseava em duas estratégias. Uma dessas estratégias diplomáticas consistia no que pode ser designada de "shoe-leather diplomacy", baseada em visitas regulares aos espaços públicos frequentados por diplomatas estrangeiros e oficiais de embaixadas. A segunda estratégia diplomática, chamada de diplomacia congratulatória, focava-se no uso deliberado de dias nacionais como mecanismo que possibilitava a comunicação diplomática e fortalecia as ligações com o país destinatário das mensagens.

\section{INDEX}

Mots-clés: PAIGC, diplomatie de libération, « shoe-leather diplomacy », diplomatie congratulatoire, bloc communiste

Palavras-chave: PAIGC, diplomacia de libertação, "shoe-leather diplomacy", diplomacia congratulatória, bloco comunista

Keywords: PAIGC, diplomacy of liberation, shoe-leather diplomacy, congratulatory diplomacy, communist bloc

\section{AUTHOR}

\section{ABEL DJASSI AMADO}

Department of Political Science and International Relations, Simmons University, United States amadoa[at]simmons.edu 